\title{
Introduction to Precipitation Runoff Process and Soil Erosion Risk Analysis in a Specific Area of Interest to Design Control Measures
}

\author{
Elena Aydin ${ }^{1 *}$, Jaroslav Antal ${ }^{1}$ \\ 1 Department of Biometeorology and Hydrology, Faculty of Horticulture and Landscape Engineering, Slovak \\ University of Agriculture in Nitra, Hospodárska 7, 94976 Nitra, Slovak Republic \\ * Corresponding author's e-mail: elenaaydin.sk@gmail.com
}

\begin{abstract}
The knowledge on the spatial variability and hydrological behaviour of contributing areas to specific outlet is a fundamental input for developing appropriate water resource planning and management actions that take part in various areas of human activities. The aim of this contribution is to present the possibilities to assess the precipitation-runoff process and soil erosion risk in a specific area using the theoretical approaches with the simplest requirements for meteorological and surface runoff data. Considering the connectivity and behaviour of natural processes, the analysis of precipitation-runoff process and soil erosion risk is crucial prior to the design of technical water management practices and technical erosion control measures in the landscape. The characteristics of design rain, e.g. the intensity, annual frequency and duration can be determined using practical tools or according to the analysis of the cost and damages related to specific technical measure. The intensity of design rain can be estimated according to the long-term meteorological observations and intensity-duration-frequency curves developed using region specific equations (Dub's formula, Urcikan's formula). For the design of water management, conservation (especially erosion) or other measures for ecological stabilization and protection of the area, it is important in particular to determine the following characteristics of surface runoff: beginning of surface runoff, design discharge from the contributing area, the depth of the surface runoff, and the volume of surface runoff. Estimating the soil erosion risk by water erosion can be done according to the slope gradient or USLE calculation and subsequent comparison of estimated value with tolerable soil loss. Regardless of the location of specific areas, we have found that the design parameters of water management and technical erosion control practices, facilities and measures, including their localization can be determined by applying and modifying the existing theoretical and practical hydrological knowledge. We also found that this design cannot be executed without an analysis of the precipitation-runoff process and the erosion risk of this territory. In relation to the climate change and changing rainfall patterns in all regions worldwide, further studies should be conducted to specify the regional characteristics of precipitation, soil and its usage.
\end{abstract}

Keywords: land consolidation, catchment, soil loss, intensity-duration-frequency relationship,

\section{INTRODUCTION}

The knowledge on the spatial variability and hydrological behaviour of catchments is a fundamental input for developing appropriate water resource planning and management actions [Chiang, Tsay and Nix, 2002] that take part in various areas of human activities (e.g. land consolidation, soil fund organization, landscape planning, integrated catchment management, soil erosion control, maintenance of water resources) [Tárník and
Igaz, 2015; Kaletová and Németová, 2017; Tárník and Leitmanová, 2017]. The following activities need to be carried out for the design of technical water management practices and technical erosion control measures in the area of interest:

1. analysis of precipitation-runoff process;

2. analysis of soil erosion risk;

3. design and dimensioning of necessary water management and technical erosion control practices, facilities and measures, including their localization [Muchová and Antal, 2013]. 
Land consolidation projects play an important role in the consolidation of fragmented agricultural land and in the improvement of the spatial structure of Slovak agriculture as well as the agriculture of other European countries: Poland [Leń and Król, 2016], Czech Republic, Germany, Hungary and Austria [Muchová and Antal, 2013]. The aim of modern land consolidation is also the management and conservation of the natural environment of rural areas through agricultural diversification:

- limitation of soil erosion by means of special formation of farmland areas and of the roads used for framing transport;

- maintenance and care of the existing mid-field tree lines and groups and the design of new ones for the improvement of microclimate of areas with low level of afforestation;

- creation of ecological corridors (afforestation) conducive to the migration of animals;

- conservation of buffer zones around water reservoirs for their protection against synthetic plant protection agents and fertilisers [Leń and Król, 2016].

Land consolidation projects are realised on "specific areas" of interest (SA) that are defined and delineated in the landscape. SAs are very often defined not based on the natural characteristics (such as watersheds, subwatersheds) but also on the basis of ownership or political decisions (e. g. cadastral areas, regions, state borders). On the basis of the theoretical analysis, three characteristic situations for the localization of SA can be identified [Muchová and Antal, 2013]:

1. the border of SA is identical with the watershed divide (Figure 1a);
2. the border of SA is located within the same watershed but is not is identical with the watershed divide (Figure 1b);

3. the border of SA is part of several watersheds (Figure 1c). For the later cases, the runoff processes has to be evaluated taking into account the inflow of water from outside of the SA border and only to the outflow cross-section from $\mathrm{SA}$, respectively.

Aside from the land consolidation projects, the planning and design of most small to large water resource development projects has usually necessitated the estimation of the runoff potential and subsequent soil erosion risk within a targeted catchment [Mekonnen, Melesse and Keesstra, 2016].

In order to analyse the precipitation-runoff process, the relationship between the intensity, duration and frequency of rainfall (the IDF relationship) is one of the most commonly used tools in water resources engineering, either for the planning, design and operation of water resource projects or the protection of various engineering projects against floods. Since the establishment of such relationships in the 1930s, different forms of relationships have been constructed for several regions of the world [Bara et al., 2010].

In general, the analysis of the precipitationrunoff process and soil erosion risk in particular areas requires various input map information at the sufficient scale, such as watershed divide map of main watershed and subwatersheds, map of slope lines (lines in the direction of the steepest slope), hydrolines and thalwegs, maps of areas, lines and points of concentration and diversion of surface runoff as well as distance map of pre-

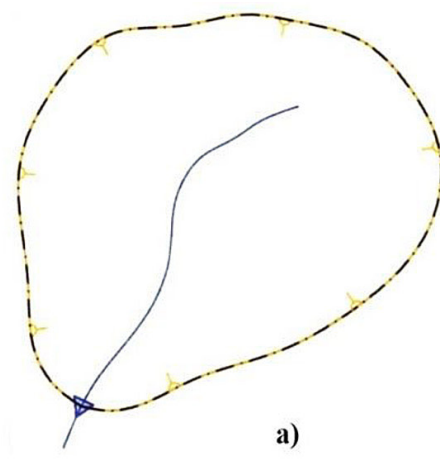

LEGEND

$\checkmark$ watershed divide border of SA

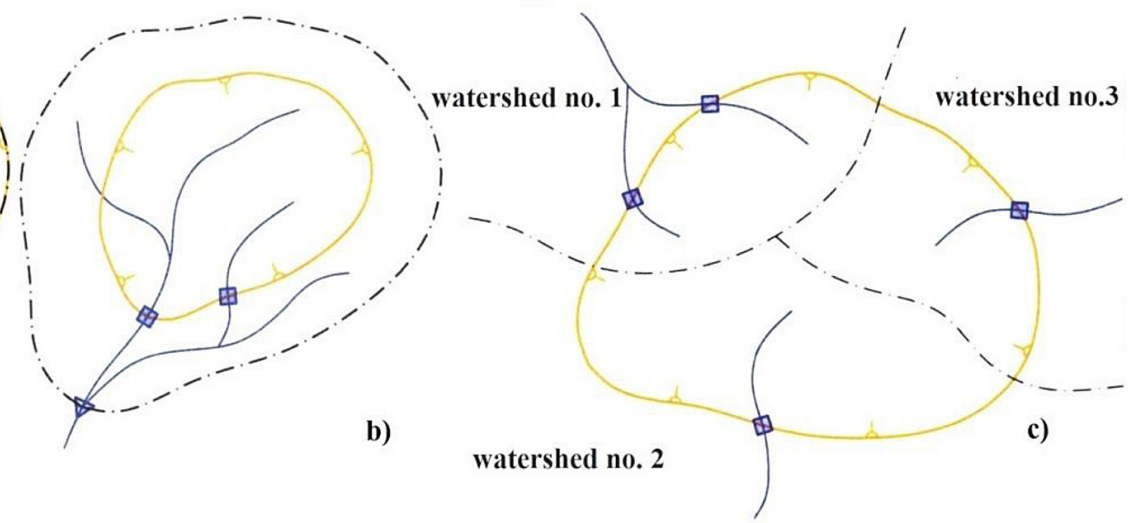

outlet crossection from watershed outflow crossection from SA

Figure 1. Specific area of interest (SA) and positioning of its border within the landscape [Muchová and Antal, 2013, modified by authors] 
cipitation water surface runoff between the watershed divide and hydrolines (map of continuous runoff of precipitation water). Nowadays, this information can be obtained in GIS environment using precise digital elevation model as an input subjected to mathematical modelling [Šinka, Muchová and Konc, 2015].

The aim of this contribution is to present the possibilities to assess the precipitation-runoff process and soil erosion risk in a specific area using the theoretical approaches with the simplest requirements for meteorological and surface runoff data.

\section{METHODOLOGY}

For the purposes of design (dimensioning) of technical water management measures and erosion control measures it is necessary that the analysis of the precipitation-runoff process and the water erosion processes in the area of interest would originate particularly from the knowledge on:

- the design rain properties;

- and surface runoff properties.

Design rain at a specific location and for the purposes of specific technical measure is unambiguously defined by the periodicity of its occurrence (annual frequency) (p), return period $(\mathrm{N})$, its duration $\left(\mathrm{t}_{\mathrm{D}, \mathrm{N}}\right)$, abundance of design rain $\left(\mathrm{q}_{\mathrm{D}, \mathrm{N}}\right)$ and its intensity $\left(\mathrm{i}_{\mathrm{D}, \mathrm{N}}\right)$ [Muchová and Antal, 2013].

For the design of water management measures, conservation (especially erosion) measures or other measures for ecological stabilization and protection of the area, it is important to particularly determine the following characteristics of surface runoff:

- beginning of surface runoff $-\mathrm{t}_{\mathrm{p}}[\mathrm{min}]$;

- design discharge from the contributing area $\mathrm{Q}_{\mathrm{N}}\left[\mathrm{m}^{3} \cdot \mathrm{s}^{-1}\right]$

- the depth of the surface runoff from the study area caused by specific usually design rain $\mathrm{H}_{\mathrm{o}, \mathrm{p}}[\mathrm{mm}]$

- volume of surface runoff from the study area caused by specific rain $-\mathrm{Oo}_{, \mathrm{p}}\left[\mathrm{m}^{3}\right]$.
Worldwide known Soil Conservation Service curve number (CN) method (Chow, 1964) that is used e.g. in catchment scale calculations of sediment delivery ratio and the amount of direct surface runoff [Šinka and Kaletová, 2013] can be used to estimate the potential (maximum) retention and the depth of direct runoff while it takes into account specific soil hydrological properties, the quality of soil cover and land use and especially for providing instant runoff data in remote catchments without the data recording equipment [Zelelew, 2017].

In the Slovak Republic, soil erosion is the most significant form of soil physical degradation. It threatens more than $50 \%$ of the total area of agricultural land [Jambor and Ilavská, 1998]. The fastest assessment of physical soil degradation occurrence in the study area is provided by the purposeful interpretations of the results of soil quality/price assessment done during Complex Soil Survey. The Methodological Handbook of Erosion Control Soil Cultivation [Jambor and Ilavská, 1998] categorizes the soil erosion according to the slope at the site into four groups, namely: soils not endangered to moderately threatened, medium, strong and extremely endangered soils by erosion (Table 1). Unlike in the case of the other approach widely used in Slovakia and worldwide (1), no other erosion factors on the site are considered.

The intensity of soil erosion by water can also be determined using modelling and thus mathematical approaches such as the Universal Soil Loss equation (USLE) in the form (Eq. 1) [Wischmeier and Smith, 1978]:

$$
A=R \cdot K \cdot L \cdot S \cdot C \cdot P
$$

where: $A-$ mean annual soil loss $\left[\right.$ t.ha $\left.{ }^{-1} \cdot \mathrm{y}^{-1}\right]$;

$R$ - rainfall erosivity factor [MJ. $\left.\mathrm{mm} \cdot \mathrm{ha}^{-1} \cdot \mathrm{h}^{-1} \cdot \mathrm{y}^{-1}\right]$;

$K \quad-$ soil erodibility factor

[t.ha.h.ha ${ }^{-1} \cdot \mathrm{MJ}^{-1} \cdot \mathrm{mm}^{-1}$;

$L-$ slope length factor [-];

$\mathrm{S}$ - slope gradient factor [-];

$C$ - cropping factor [-];

$P$ - conservation practice factor[-].

Table 1. Categories of soil endangerment by water erosion according to the slope gradient [Jambor and Ilavská, 1998]

\begin{tabular}{|c|c|c|c|}
\hline Erosion category & Slope gradient & Type of erosion & Intensity [t.ha-1. $\left.\mathrm{y}^{-1}\right]$ \\
\hline 1 & $0-3^{\circ}$ & Not endangered up to moderately threatened soil & $0-4$ \\
\hline 2 & $3-7^{\circ}$ & Medium erosion & $4-10$ \\
\hline 3 & $7-12^{\circ}$ & Strong erosion & $10-30$ \\
\hline 4 & $>12^{\circ}$ & Extreme erosion & $>30$ \\
\hline
\end{tabular}




\section{RESULTS}

\section{Estimation of design rain properties}

Design rain characteristics can be determined by means of various practical tools. Simpler approaches such as the ones shown in Table 2 take into account predominantly the land use and slope characteristics of the specific area of interest.

Function analysis (Eq. 2) takes into direct consideration the expected cost to establish the technical measure and the cost for removing the damages the natural process can cause.

$$
\Sigma(\text { cost }+ \text { damage })=\mathrm{f}(\mathrm{N})
$$

where: $N$ is determined at the point where function

$\Sigma$ (cost + damage $)$ has a minimum value - Figure 2.

The critical duration of design rain $\left(t_{D, N, \text { rrit }}\right)$ can be also determined by the function analysis (Eq. 3) [Muchová and Antal, 2013].

$$
\mathrm{q} 100=\mathrm{f}\left(\mathrm{t}_{\mathrm{D}, \mathrm{N}} \leq \tau_{\max }\right)
$$

where: $\tau_{\max }$ is concentration time and

$t_{D, N, \text { crit }}$ is determined at the point where function (Eq. 3) reaches its maximum value (Figure 3 ).

The relationship between the design rain intensity (or abundance), its duration and the annual frequency (or return period) for a particular location $\mathrm{i}_{\mathrm{D}, \mathrm{N}}\left(\right.$ or $\left.\mathrm{q}_{\mathrm{D}, \mathrm{N}}\right)=\mathrm{f}\left(\mathrm{t}_{\mathrm{D}, \mathrm{N}}, \mathrm{p}\right.$, locality characteristics) is expressed by lines of alternate (design) rain intensities (abundances) of torrential rains (Figure 4). In Slovakia, the IDF relationship can be obtained by:

- processing long-term (> 30 years) ombrographic observations at the site;

- requesting and processing design rain characteristic for a specific location from the relevant branch of Slovak Hydrometeorological Institute (the most accurate data);

- calculating according to the equations (Eq. 4), (Eq. 5) [Antal et al., 2014].

In order to calculate the design rain intensity, Dubs equation (Eq. 4) and Urcikáns equation (Eq. 5) are most frequently used under the conditions of Slovakia [Antal et al., 2014], when design rain intensity is calculated after unit conversion from design rain abundance.

$$
q_{D, N}=\frac{3200}{\left(t_{D, N}+b\right)^{0,675} \cdot(150 \cdot p)^{n}}
$$

$$
q_{D, 100}=\frac{K}{t_{d, N}^{a+B}} \cdot 10^{-6}
$$

where: $q_{D, N}$ - abundance of design rain $\left[1 . \mathrm{s}^{-1} \cdot \mathrm{ha}^{-1}\right]$; $q_{D, 100}-$ abundance of design rain with a return period of $\mathrm{N}=100$ years $\left[\mathrm{m}^{3} \cdot \mathrm{s}^{-1} \cdot \mathrm{m}^{-2}\right]$

$p-(>0.1)$ annual frequency of design rain;

$n, b, K, B, a$ - site specific parameters (determined for example according to Antal et al. [2014]);

$t_{d, N}-$ duration of design rain [min].

The rainfall IDF relationships worldwide are expressed in various formats (e.g. in USA isohyetal maps, atlases with combination of recurrence interval and duration of rain for different regions). Various methods are used to evaluate the frequency of the rainfall such as: Bilham method, Federick Charles Bell, and NERC (Natural Environment Research Council. Chen utilized a method similar to the Bell method and it was used for IDF evaluation in Jordan [Hadadin, 2005]. Elsebaie

\begin{tabular}{|c|c|c|c|}
\hline $\begin{array}{l}\text { Subdivision of agricultural } \\
\text { production }\end{array}$ & $\begin{array}{l}\text { Exposure of the production areas; } \\
\text { Soil surface gradient }\end{array}$ & $\begin{array}{l}\text { Design rain annual } \\
\text { frequency }\end{array}$ & $\begin{array}{l}\text { Design rain } \\
\text { duration ( } \mathrm{min})\end{array}$ \\
\hline \multirow[b]{2}{*}{ Plant production } & distant from residential area & 0.20 & 30 \\
\hline & $\begin{array}{l}\text { in contact with residential area, resp. object of higher } \\
\text { order }\end{array}$ & 0.10 & 30 \\
\hline Meadow production & without specification & 0.20 & 30 \\
\hline \multirow{3}{*}{$\begin{array}{l}\text { Special production } \\
\text { (vineyards, orchards) }\end{array}$} & $\begin{array}{l}\text { I. category of slope gradient } \\
(0-10 \%)\end{array}$ & 0.20 & 15 \\
\hline & $\begin{array}{l}\text { II. and III. category of slope gradient } \\
(10-45 \%)\end{array}$ & 0.10 & 15 \\
\hline & $\begin{array}{l}\text { II. and III. category of slope gradient in contact with } \\
\text { residential area, resp. object of higher order }\end{array}$ & 0.05 & 15 \\
\hline
\end{tabular}
[2012] in his study conducted in Saudi Arabia used Gumbel and LPT III distribution method for

Table 2. The properties of design rain for erosion control purposes [STN 74501, 2000] 
the formulation and construction of IDF curves using the data from recording stations.

\section{Estimation of surface runoff properties}

Among the many principles to reduce the risk of soil degradation by water erosion (e.g. protection of the soil surface from the impact of rain drops, increasing the surface roughness of the soil), the most important one is that "If there is no surface runoff, there is no soil erosion by water" [Antal, 1985].

The surface runoff of the precipitation water on the slope occurs when the intensity of the rain in the specific time $-i_{D, t}$ is greater than the infiltration capacity of the soil $-v_{i, t}$ (Eq. 6) or when the depth of the design rain $-\mathrm{H}_{\mathrm{D}, \mathrm{N}}$ is greater than the surface retention of the investigated slope $H_{R}$ (Eq. 7).

$$
\begin{aligned}
& \mathrm{i}_{D, t}>\mathrm{V}_{\mathrm{i}, \mathrm{t}} \\
& \mathrm{H}_{\mathrm{D}, \mathrm{N}}>\mathrm{H}_{\mathrm{R}}
\end{aligned}
$$

By adjusting the equations for calculating the depth of surface runoff and the potential retention of the investigated slope (watershed) using the Soil Conservation Service Curve Number method (SCS CN), we obtain the equation (Eq. 8) for calculating the maximum depth of design rain $\left(\mathrm{H}_{\mathrm{D}, \max }\right)$ that would not yet cause surface runoff [Antal, 1985, modified]:

$$
\mathrm{H}_{\mathrm{D} \text {, max }}=5080 / \mathrm{CN}-50.8
$$

where: $H_{D, \max }-$ maximum depth of design rain that does not yet cause surface runoff, i.e., surface retention of the investigated slope $-\mathrm{H}_{\mathrm{R}}[\mathrm{mm}]$;

$\mathrm{CN}-$ representative $\mathrm{SCS} \mathrm{CN}$ value of the investigated slope as a function of its vegetation cover and hydrological category of soil [Chow, 1964].

Table 3 shows the estimated $\mathrm{H}_{\mathrm{D} \text {, max }}$ values for field crops grown at the individual hydrological soil categories.

SCS CN has been applied throughout the world [Šinka and Kaletová, 2013; Zelelew, 2017]. However, several authors [e.g. Steenhuis et al., 2009; White et al., 2011] have questioned the representativeness of the approach in different climates and geological settings as it was originally developed for the applications in temperate regions, especially in the United States. Thus,

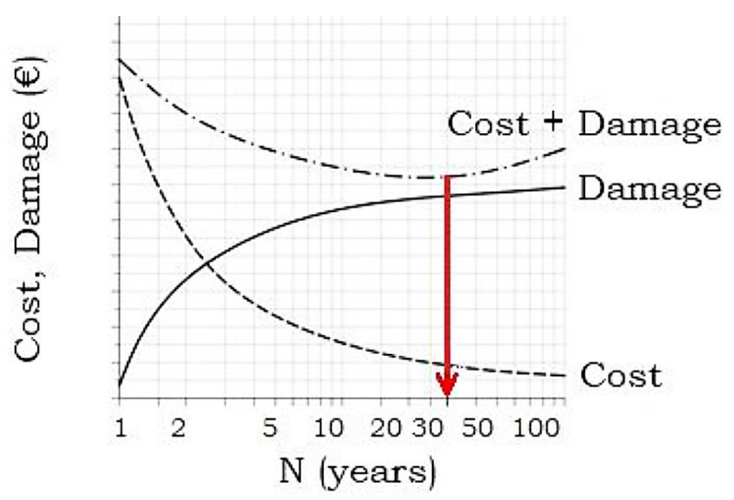

Figure 2. The principle of estimation of design rain return period $-\mathrm{N}$. In this example $\mathrm{N}=30$ years which equals to annual frequency of 0.03 [Muchová and Antal, 2013, modified by authors]

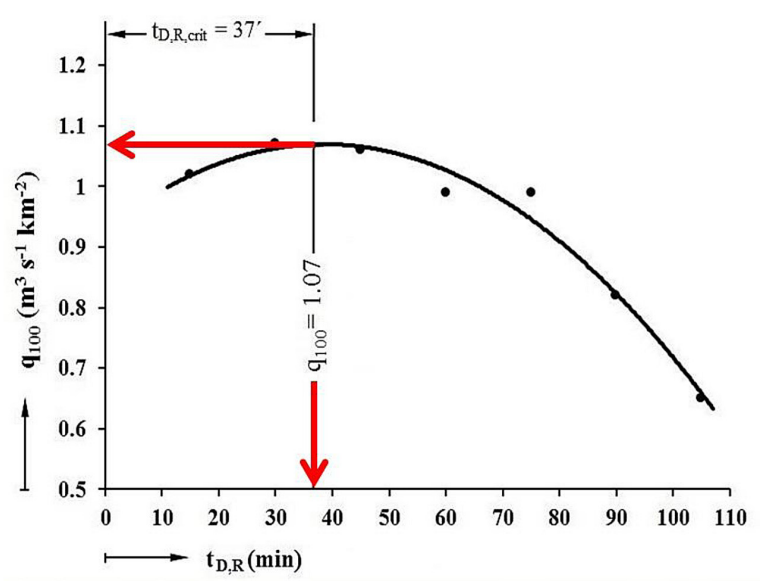

Figure 3. Evaluation of the function course $\mathrm{q}_{100}=\left(\mathrm{t}_{\mathrm{D}, \mathrm{R}}\right.$ $\left.\leq \tau_{\max }\right)$ and determination of $t_{\mathrm{D}, \mathrm{R}, \text { crit }}$. In this example $\mathrm{t}_{\mathrm{D}, \mathrm{N}, \text { crit }}=37 \mathrm{~min}$ [Antal et al., 2014, modified by authors]

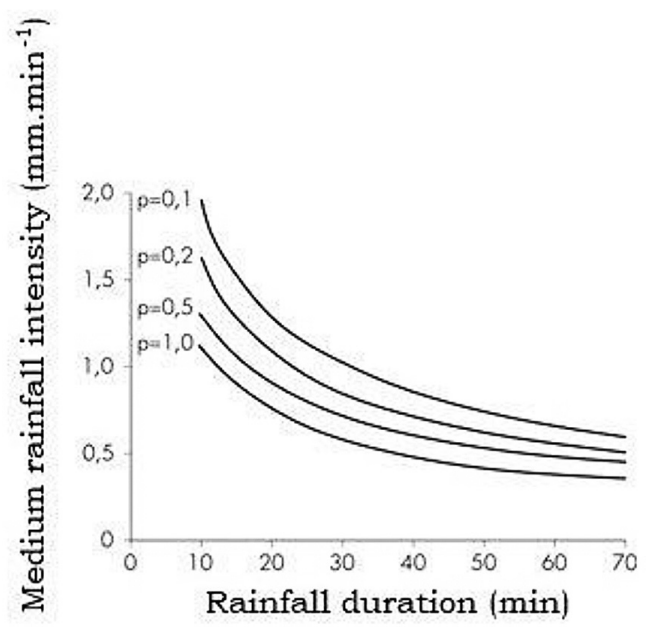

Figure 4. Lines of alternate (design) rain intensities (abundances). Intensity-duration-frequency relationships for torrential rains [Antal et al., 2014] 
country-specific verification using measured data is recommended [Dile et al., 2016].

By analysing the formation of surface runoff on agricultural land we found that - with the exception of sandy soils - it is possible to prevent the formation of surface runoff in field crops caused by design rain estimated for erosion control (Table 2) only by the application of some technical or biotechnical erosion measures [Antal, 1985].

The calculated intensity of water erosion can be compared with the value of the permissible (tolerated) soil loss intensity $\left(\mathrm{S}_{\mathrm{p}, \text { tol }}\right.$ ) (Table 4). In Slovakia, the individual limiting values of erosion soil loss are a function of the soil depth.

\section{CONCLUSIONS}

1. Rainfall is one of the most important sources of water. However, its random occurrence sometimes creates a lot of problems. The catchment response to the rainfall events may cause considerable damage to development in the surrounding landscape. Planning and protection of such a catchment, its agricultural land and urban areas requires estimates of expected discharge from the rainfall events of different magnitudes. Our contribution presents some insight into the way in which the precipitationrunoff process and soil erosion risk in a specific area can be estimated using the theoretical approaches with the simplest requirements for meteorological and surface runoff data. The procedure, described in the methodology and results of this work can be used for the assessment of precipitation-runoff process and soil erosion risk also in other countries worldwide. It should be kept in mind that the soil erosion risk of the site cannot be assessed without the knowledge on the precipitation-runoff processes at the specific area of interest. Since without surface runoff, there is no soil erosion by water.

2. USLE and SCS CN methods are used worldwide; thus, the results of the studies using these approaches can be comparable. Additionally, these empirical approaches require significantly less input data than the newer mathematical models of erosion and deposition processes. However, the representativeness of the results should be verified by real measurements. In the field the more natural conditions differ from the country (USA) where these approaches were originally developed.
Table 3. Estimated maximum depth of design rain $\left(\mathrm{H}_{\mathrm{D}, \max }\right)$ for field crops [Muchová and Antal, 2013]

\begin{tabular}{|c|c|}
\hline $\begin{array}{c}\text { Hydrologic soil categories according to } \\
\text { SCS CN method [Chow, 1964] }\end{array}$ & $\mathrm{H}_{\mathrm{D}, \max }[\mathrm{mm}]$ \\
\hline A & 27 \\
\hline B & 17 \\
\hline C & 13 \\
\hline D & 9 \\
\hline
\end{tabular}

Table 4. Tolerable soil loss intensity [Act No.220/2004 Coll.]

\begin{tabular}{|l|c|}
\hline \multirow{2}{*}{ Soil depth } & $\begin{array}{c}\text { Tolerable soil loss intensity by } \\
\text { water erosion as a function of } \\
\text { soil depth }\end{array}$ \\
\cline { 2 - 2 } & $\mathrm{S}_{\mathrm{p}, \text { tol. }}\left[\mathrm{t}^{\mathrm{N}} \mathrm{h}^{-1} . \mathrm{y}^{-1}\right]$ \\
\hline Shallow soils $(<0.3 \mathrm{~m})$ & 5 \\
\hline $\begin{array}{l}\text { Medium deep soils } \\
(0.3-0.6 \mathrm{~m})\end{array}$ & 10 \\
\hline Deep soils $(0.6-0.9 \mathrm{~m})$ & 15 \\
\hline Very deep soils $(>0.9 \mathrm{~m})$ & 20 \\
\hline
\end{tabular}

3. Regarding the IDF curves, the applicability of methodology described in this paper is limited to Slovakia and the locations near the Slovak borders, due to dependence of the equations (e.g. Eq. 5) on parameters that are site specific and were developed for specific regions of Slovakia using long-term observations of meteorological data. Although other European countries and the countries outside Europe use different calculations, their principle is the same and they originate from the analytical expression of the IDF curves.

4. In relation to the climate change and changing rainfall patterns in all regions worldwide, further studies should be conducted to specify the regional characteristics of precipitation, soil and its usage. Increasing occurrence of torrential rains with short duration and high intensity requires attention to consider the existing methods of IDF relationships evaluation and subsequent usage of the input values for the purposes of land management and development.

\section{Acknowledgements}

This study was supported with the following grants and projects:

- VEGA 1/0268/14: Integrated protection of soil and water resources in agricultural land; 
- KEGA 026SPU-4/2017: Innovative application of optic method in soil science: laser diffraction by soil texture analysis;

- APVV SK-AT-2017-0008: Application of the connectivity concept in water erosion research for the purposes of integrated catchment protection.

\section{REFERENCES}

1. Act No.220/2004 Coll. on protection and utilisation of agricultural land (in Slovak).

2. Antal J. 1985. Soil conservation and forest amelioration II. Exercise guide. VŠP in Nitra, Nitra (in Slovak).

3. Antal J., Bárek V., Čimo J., Halaj P., Halászová K., Horák J., Igaz D., Jurík L., Muchová Z., Novotná B., Šinka K. 2014. Hydrology of agricultural land. SPU in Nitra, Nitra (in Slovak).

4. Bara M., Kohnová S., Gaál L., Szolgay J., Hlavčová K. 2010. Estimation of IDF curves of extreme rainfall by simple scaling in Slovakia. Contributions to Geophysics and Geodesy, 39 (3), 187-206.

5. Chiang S., Tsay T.K., Nix S.J. 2002. Hydrologic regionalization of watersheds I: Methodology development. Journal of Water Resources Planning and Management, 128(1), 3-11.

6. Chow V. T. 1964. Handbook of applied hydrology: a compendium of water-resources technology. McGraw-Hill, New York.

7. Dile Y.T., Karlberg L., Srinivasan R., Rockström J. 2016. Investigation of the curve number method for surface runoff estimation in tropical regions. Journal of the American Water Resources Association, 52 (5), 1155-1169.

8. Elsebaie I.H. 2012. Developing rainfall intensityduration-frequency relationship for two regions in Saudi Arabia. Journal of King Saud University Engineering Sciences, 24, 131-140.

9. Hadadin N.A. 2005. Rainfall intensity-durationfrequency relationship in the Mujib Basin in Jordan. Journal of Applied Sciences, 5 (10), 1777-1784.

10. Jambor P., Ilavská B. 1998. Methodology of erosion control tillage systems. VÚPÚ, Bratislava (in Slovak).

11. Kaletová T., Németová Z. 2017. Determination of surface runoff from the modelled area. Environment, earth and ecology, 1 (1), 61-66.
12. Leń P., Król Ż. 2016. Analysis of economic and environmental effects of land consolidation on the example of Hucisko village. Journal of Ecological Engineering, 17 (5), 232-239.

13. Mekonnen M., Melesse A.M., Keesstra S.D. 2016. Spatial runoff estimation and mapping of potential water harvesting sites: A GIS and remote sensing perspective, Northwest Ethiopia. p. 565-584. In Landscape dynamics, soils and hydrological processes in varied climates. Cham: Springer.

14. Muchová Z., Antal J. 2013. Land consolidation. SPU in Nitre, Nitra (in Slovak).

15. Steenhuis T.S., Collick A.S., Easton Z.M., Leggesse E.S., Bayabil H.K., White E.D., Awulachew S.B., Adgo E., Ahmed A.A. 2009. Predicting discharge and sediment for the Abay (Blue Nile) with a simple model. Hydrological Processes, 3737, 3728-3737.

16. STN 75 4501. 2000. Hydro-melioration. Erosion control of agricultural land. Fundamental terms (in Slovak).

17. Šinka K., Kaletová T. 2013. Determining the characteristics of direct runoff from real rain using GIS environment. Acta Horticulturae et Regiotectuare. 16 (2), 48-52.

18. Šinka K., Muchová Z., Konc L. 2015. Geographical information systems in spatial planning SPU, Nitra (in Slovak).

19. Tárník A., Igaz D. 2015. Determination of plant available soil water storage in agricultura land of the Nitra river catchment. Acta Horticulturae et Regiotecturae. 18 (1), 16-19.

20. Tárník A., Leitmanová M. 2017. Analysis of the development of available soil water storage in the Nitra river catchment. IOP Conf. Series: Materials Science and Engineering, 1-8.

21. White E.D., Easton Z.M., Fuka D.R., Collick A.S., Adgo E., McCartney M., Awulachew S.B., Selassie Y.G., Steenhuis T.S. 2011. Development and application of a physically based landscape water balance in the SWAT model. Hydrological Processes, (25) 915-925.

22. Wishmeier W.H., Smith D.D. 1978. Predicting rainfall erosion losses - a guide to conservation planning. Agriculture handbook no. 537. U. S. Department of Agriculture, Hyatsville.

23. Zelelew D.G. 2017. Spatial mapping and testing the applicability of the curve number method for ungauged catchments in Northern Ethiopia. International Soil and Water Conservation Research, 5, 293-301. 